\title{
3.- CAMBIOS PERCIBIDOS EN LOS ROLES DE CUIDADORAS FAMILIARES DE HOMBRES SOBREVIVIENTES DE ACCIDENTE CEREBROVASCULAR
}

\author{
CHANGES PERCEIVED IN THE ROLES OF FAMILY CAREGIVERS OF SURVIVING MEN \\ OF CEREBROVASCULAR ACCIDENT
}

\begin{abstract}
RESUMEN
La presente es una investigación exploratoria de tipo cualitativa con un enfoque fenomenológico, cuyo objetivo fue explorar los cambios percibidos en los roles de cuidadoras familiares de hombres sobrevivientes de un accidente cerebrovascular durante el primer año posterior al accidente cerebrovascular, para lo cual se entrevistó a cinco cuidadoras familiares realizándose dos entrevistas a cada una de ellas. El análisis de los datos se realizó teniendo como base la teoría fundamentada, utilizándose el método de comparación constante.

Como resultado se obtuvo que los cambios en los roles de las cuidadoras incluyeron la adquisición de nuevos roles, pérdida y complejización de roles previos, los que fueron generados por la adquisición del rol de cuidadora familiar. Los cambios en los roles provocaron en las cuidadoras una sobrecarga de roles, generándoles desequilibrio ocupacional, ante lo cual las cuidadoras aplicaron variadas estrategias que les permitieron modificar el desempeño de sus roles con el fin de restablecer su equilibrio ocupacional. Factores propios de las cuidadoras familiares del sobreviviente del accidente cerebrovascular, de la relación entre la cuidadora familiar y el sobreviviente del accidente cerebrovascular, de la transición que provocó la adquisición del rol de cuidadora familiary del ambiente físico y social en el cual se realizó el cuidado ejercieron una influencia en el proceso de cambio en los roles y de recuperación del equilibrio ocupacional de las cuidadoras familiares.

En conclusión, los cambios en los roles abarcaron a la mayoría de los roles desempeñados por las cuidadoras familiares. Conocer las estrategias de equilibrio en el desempeño de los roles utilizadas por las cuidadoras puede contribuir al diseño e implementación de abordajes terapéuticos del desequilibrio ocupacional. Identificar factores que se constituyen como barreras al proceso de restablecimiento y mantención del equilibrio ocupacional puede aportar a identificar grupos de riesgo en los futuros cuidadores familiares de sobrevivientes de accidentes cerebrovasculares que permita focalizar las intervenciones de terapia ocupacional.
\end{abstract}

\section{PALABRAS CLAVES}

Roles ocupacionales - cuidador familiar - accidente cerebrovascular

\begin{abstract}
The present is a qualitative exploratory research, with a phenomenological approach, whose objective was to explore the perceived changes in the roles offamily caregivers of men survivors of a stroke during theirfirst year of survivorship after the stroke. For which five family caregivers were interviewed carrying out two interviews to each of them. Data analysis was made based on the grounded theory, using the constant comparison method.

As a result, it was founds that changes in caregivers roles included the acquisition, loss and complexity of previous roles, which were generated by acquiring the family caregiver role. The changes in roles caused in caregivers an overload of roles, generating occupational imbalance, in the face of which caregivers applied various strategies that allowed them to modify the performance of their roles directed to restore their occupational balance. Factors own offamily caregivers, of stroke survivor, of the relationship between the family caregiver and stroke surviver, of the transition that causes the acquisition of the family caregiver role and of the physical and social environment in which the care exercised an influence on the process of changing roles and recovering the occupational balance offamily caregivers.
\end{abstract}


In conclusion, changes in roles encompass the most of roles played by family caregivers. Knowing the strategies of balance in performance of the roles used by the caregivers can contribute in the design and implementation of therapeutic approaches to their occupational imbalance. Identifying factors that constitute barriers to the process of restoration and maintenance of the occupational balance can contribute to identify groups of risk in futures family caregivers of stroke survivors that allows targeting occupational therapy interventions.

\section{KEYWORDS}

Occupational roles - family caregiver - stroke

IRMA Ester Fonseca Mardones Terapeuta Ocupacional, Diplomada en Docencia en Ciencias de la Salud. Universidad de Chile, Magíster en Ocupación y Terapia Ocupacional. Terapeuta Ocupacional Hospital de la Dirección de Previsión de Carabineros de Chile. Profesora Asistente en Docencia Departamento de Terapia Ocupacional y Ciencia de la Ocupación, Universidad de Chile. Vital Apoquindo 1200, Las Condes, Santiago.irma.fonseca@gmail.com. Fono: 229517275. https://orcid.org/oooo-ooo2-9185-5631

Director de Tesis: T.O. Prof. Diego Cifuentes Lucero 